\title{
DIÁLOGOS INSURGENTES
}

Seção de entrevistas 
- Entrevista com Jorge Luiz Souto Maior Gustavo Seferian 


\section{Entrevista de Jorge Luiz Souto Maior, concedida a Gustavo Seferian, membro da Comissão de Organização do volume 5 , $n^{\circ} 2$, da revista InSURgencia}

Gustavo Seferian: Jorge - vou tomar a liberdade de te chamar assim, sem formalidades -, queria de início poder te ouvir um pouco sobre tuas impressões acerca do movimento sindical no curso da tua vida enquanto advogado, juiz e professor de direito. Muita coisa mudou desde teus primeiros passos nas carreiras jurídicas até hoje?

Jorge Luiz Souto Maior: Me formei em 1986. Já, em 1987, trabalhei como advogado em um sindicato em Pouso Alegre, MG. Mas não tinha muita compreensão do movimento sindical como um todo. Minha apreensão sobre a atuação sindical começou a ficar mais clara quando aprofundei os estudos em curso de especialização na USP, realizado em 1989, isto porque, com o advento da nova Constituição, de 1988, a participação dos sindicatos nas negociações coletivas sofreu modificações relevantes. A impressão que tive, certa ou errada, foi a de que o movimento sindical se sentiu derrotado com o resultado da Constituição e, ao invés de continuar travando uma luta no processo de interpretação das normas constitucionais, preferiu abandoná-la, acreditando que poderia traçar sua atuação exclusivamente fora do campo jurídico. Só que a década de 90 foi marcada por fortes políticas neoliberais, com patrocínio internacional, e isso atingiu mais ainda os sindicatos, sem falar no fato de que as formas jurídicas de repressão da ação sindical, instaladas no regime ditatorial, continu- 
aram, de certo modo, sendo aplicadas (vide as paradigmáticas greves de 1988 e 1995). Com a chegada do Partido dos Trabalhadores ao governo, o movimento sindical, debilitado, se engajou, prioritariamente, em lutas mais burocráticas e que não colocassem em risco a estabilidade do governo. Essa "aliança" dificultou a retomada de uma atuação sindical pelas bases, mas que, ainda assim, aos poucos, foi sendo se consolidando em muitos segmentos. A grande questão é que o abandono da luta jurídica favoreceu a consolidação da terceirização, que desvinculou o capital do trabalho. Ao mesmo tempo a luta política, governamental, se tornou o alvo prioritário da atuação sindical e isso abriu espaço ainda maior para uma restruturação produtiva extremamente arredia à coalização de trabalhadores. Sem força nas bases, o movimento sindical não conseguiu fazer resistência à contrarreforma trabalhista que aprofundou as perdas dos trabalhadores e das trabalhadoras e esfacelou a estrutura sindical. Curiosamente, no momento, o momento atual, em que os sindicatos precisam olhar para a realidade além do jurídico, parecem que estão mais preocupados em travar uma luta jurídica pela "unicidade" e pelas formas estatais de recolhimento de contribuições.

GS: Sem sair do trato do movimento sindical, queria que comentasse um pouco sobre o sindicalismo de magistrados e magistradas. Muito embora tenhamos um forte veia associativista no Brasil - exemplo disso são a AJD (Associação Juízes para a Democracia), que você anima, e tuas leituras acerca das associações profissionais em momentos cruciais da história do Direito e Justiça do Trabalho, como às vésperas da aprovação da EC n.45/2004 -, a articulação sindical, à semelhança do Syndicate de la Magistrature francês não parecem prosperar por aqui. Qual é tua opinião quanto a isso? Vê sentido em um sindicato, de aspiração não só categorial mas classista, de magistrados e magistradas?

JLSM: A magistratura será mais forte e independente, para, de fato, cumprir o seu papel institucional de fazer valer uma ordem jurídica pautada pela prevalência dos Direitos Humanos, como estabelecem 
todos os tratados internacionais, quando se perceber como poder. Há aí um paradoxo, pois os magistrados e magistradas não deixam de ser seres humanos e, mais propriamente, trabalhadores e trabalhadoras, além de cidadãs e cidadãos. Então, é legítimo que busquem se organizar coletivamente, inclusive na forma de sindicato, para a defesa de seus interesses ligados a melhores condições de trabalho e até mesmo para expressar suas posições políticas sobre temas de relevância nacional. Mas não se pode deixar que essa atuação conduza a negociações institucionais ou articulações que ponham em risco ou abalem de algum modo a condição de expressão do poder da magistratura, ou seja, que inferiram em sua independência e sua credibilidade. Quando os interesses pessoais entram em primeiro plano, gerando uma lógica circulante meramente corporativa, a organização coletiva dos magistrados pode fazer muito mal à magistratura e à ordem democrática. Nesse tema, mais do que nunca, os fins não justificam os meios.

GS: Já no que se refere a outros movimentos sociais - como os de luta pela terra, moradia e outros direitos sociais -, de que modo você os enxerga dinamizando o Direito do Trabalho?

JLSM: Acho que essa interlocução entre movimentos sociais e Direito do Trabalho não se efetivou. Os movimentos sociais cresceram muito nos últimos anos, mas o mundo do trabalho não foi capaz de se aliar a essas lutas. Quem sabe isso ainda ocorra, sobretudo nesse momento necessário de reinvenção.

GS: Jorge, você por certo foi um dos intelectuais que se colocou mais a frente no enfrentamento às contrarreformas trabalhistas no último período, sobretudo depois do golpe de 2016. De que modo você percebe as alterações dadas com as Leis n. 13.429 e 13.467/2017, bem como pelas recentes MPs de Bolsonaro no seu cotidiano da magistratura e na lida com o mundo do trabalho?

JLSM: Vejo um quadro de uma multidão sendo empurrada ladeira à baixo em direção de um precipício, com pessoas, do lado de fora, admirando, não se importando ou buscando um meio de potencia- 
lizar o empurrão, e os de dentro, rolando a ladeira, querendo achar um culpado entre eles próprios e tentando achar um meio de não continuar descendo...

GS: Falando em Bolsonaro, de que modo você percebe as recentes políticas já implementadas e por implementar pelo anti-governo neofascista no campo das relações de trabalho?

JLSM: Em termos de governo Bolsonaro acho impróprio falar em política. Não há política de nada. Há impulsos, atuações impulsivas, emocionais, irracionais e inconsequentes. No campo do trabalho, os interlocutores do governo, para manter o diálogo com o poder econômico, repetem os chavões que o mercado gosta de ouvir e, para dar demonstrações de poder, não terão o menor receio em ir destruindo as relações de trabalho com medidas incoerentes, arredias à produção nacional e degradantes da condição humana dos trabalhadores.

GS: Por fim, acompanhando tua trajetória de pertíssimo há mais de uma década, percebi um grande aumento da recepção das suas formulações fora do meio jurídico. Isso, ao menos cronologicamente, se combinou com três fatores: uma ainda mais explícita adesão ao marxismo, a formação de um grupo de pesquisa e estudos com grande adesão e reuniões periódicas, bem como a utilização de redes sociais - mais especificamente teu blog e a página do Facebook do GPTC-USP, nosso grupo de pesquisa. De que modo você vê essa combinação de fatores que, na minha leitura, te colocaram na condição de intelectual público?

JLSM: Eita, permita-me discordar. Não me vejo como intelectual. Sou um curioso inquieto. Só isso. $\mathrm{E}$ acho mesmo, sinceramente, que o tom de intelectual deixa as pessoas meio caretas, meio enquadradas. Prefiro continuar aprendendo e o que apreendo não reproduzo como dogma ou argumento fechado. $E$ acho que as lições estão mais acessíveis do que se imagina. A cada esquina, a cada aperto de mão. 
GS: De todo jeito, tomando-se como intelectual ou não, tua leitura do Direito desde o referencial marxista é bastante particular e interessante. Te defini como marxista na pergunta anterior, sei o quanto reivindica Marx em uma série de seus textos e em tua compreensão histórica, mas me diz, você se define marxista? Fala um pouco mais disso pra nós.

JLSM: Pois é, não me sinto marxista, porque para ser marxista, segundo o padrão acadêmico estabelecido, tem-se que seguir à risca as lições d'O Capital. Eu não me considero capaz de ser seguidor de nada. Prefiro entender e questionar. E acho que toda compreensão só tem sentido se servir às atuações concretas, à vida real, às relações sociais e humanas, ao tempo presente! Se para isso, a luta pelo Direito é essencial, não vou desprezá-la se a lição teórica expressar que o Direito é apenas uma forma de reprodução das forças de opressão do capital sobre o trabalho. Ainda assim, questiono se o desprezo que certos marxistas têm pelo Direito não possa ser uma deficiência de caráter teórico. Mas não me deixo perder nesse debate infindável enquanto a vida nos atropela e me pergunto: "Meus bons amigos onde estão, notícias de todos quero saber". 
